\title{
Acidophilic Thiobacilli in the River Sirppujoki
}

\author{
By S. I. NIEMELÄ AND O. H. TUOVINEN* \\ Department of Microbiology, University of Helsinki, SF-007ı Helsinki 7I, Finland
}

(Received 5 April 1972; revised 23 May 1972)

\begin{abstract}
SUMMARY
Numbers of acidophilic thiosulphate-oxidizing and iron-oxidizing thiobacilli in the River Sirppujoki (S.W. Finland) were monitored through one annual cycle. A number of physical and chemical environmental variables of the river water were determined (temperature, discharge, $\mathrm{pH}$ values, titratable acidity, and concentrations of manganese, iron and sulphate). Thiobacilli in river water appeared mainly to have been washed in from the soil. Once in the river a slow loss of viability occurred, strongly influenced by the temperature. The methods for quantitative colony counts of acidophilic thiobacilli were deemed unsatisfactory.
\end{abstract}

\section{INTRODUCTION}

Thiobacilli, particularly the acidophilic species and the iron oxidizers, are supposed to be the most important group of micro-organisms involved in the oxidation of inorganic sulphur compounds to sulphuric acid and are indigenous in acid, sulphur-containing soils (Burns, I967; Kelly, I97I).

The present study deals with the occurrence of acidophilic thiobacilli and iron-oxidizing thiobacilli in a river in which the acidity was seasonally increased by the ingress of acid runoff waters from the catchment area. Some physical and chemical factors which are assumed to be directly or indirectly associated with thiobacilli were also determined.

\section{METHODS}

Study area and sampling sites. The River Sirppujoki $\left(60^{\circ} 50^{\prime} \mathrm{N}, 21^{\circ} 30^{\prime} \mathrm{E}\right)$, with a catchment area of $430 \mathrm{~km}^{2}$, runs through the coastal plain of S.W. Finland where the soil is mainly ancient sea bottom characterized by clay with a high sulphide content (Purokoski, 1958). A further characteristic of the system is the lack of regulation by large lake basins making the stream-flow very responsive to variations in surface run-off. Seasonal variation of the acidity of the waters in the district has been reported (Isotalo, 1971).

The sampling sites ' $O$ ' and ' 2 ' were situated on the Sirppujoki itself and site ' $I$ ' on an acid tributary. During the observation period the $\mathrm{pH}$ value of the main stream occasionally dropped below $\mathrm{pH} 4.5$ whereas in the tributary, $\mathrm{pH}$ values below 4.5 were the rule.

Sampling. A total of 22 sampling dates were evenly spaced throughout a nearly complete annual cycle from July i 969 to May 1970. Duplicate water samples were brought to the laboratory in Helsinki (distance $250 \mathrm{~km}$ ) for analysis. The time between sampling and cultivation of bacteria varied between 24 and $28 \mathrm{~h}$.

Acidophilic thiobacilli. Difco Thiobacillus-Agar ( $\left.\mathrm{pH}_{4} \cdot 8\right)$ was used for colony counts of

* Present address: Department of Microbiology, Queen Elizabeth College, Atkins Building, Campden Hill, London, W8 7 AH. 
acidophilic thiobacilli. Triplicate platings were made from the parallel samples and the six counts were combined into one average estimate.

Silverman \& Lundgren's (1959) liquid medium, with $2 \cdot 0 \mathrm{~g} \mathrm{Fe}^{2+} / 1$, was used for the determination of most-probable-number (MPN) estimate of iron-oxidizing bacteria (Tuovinen, Niemelä \& Gyllenberg, 197I). Elective cultures were prepared using three tenfold dilutions (in the range $1 \mathrm{I}^{-1}$ to $\mathrm{IO}^{-5}$, depending on bacterial concentration) of each pair of water samples. This collection was treated as if it were a $3 \times 2$ flask MPN arrangement. The actual values were calculated according to Fisher \& Yates (1963).

Incubation. The agar plates were incubated for Io days at $28^{\circ} \mathrm{C}$ and the liquid cultures on a New Brunswick rotary shaker at $28^{\circ} \mathrm{C}$ and $200 \mathrm{rev}$./min for up to 6 weeks.

Physical and chemical determinations. Water temperature was recorded at site ' $\mathrm{o}$ '. $\mathrm{pH}$ Values were measured in water samples transported to the laboratory. River discharge data for sampling sites ' $I$ ' and ' $O$ ' were obtained from the Turku District Office of the National Board of Waters, who also determined the phenolphthalein acidity, iron, manganese and sulphate values in parallel water samples according to Standard Methods for the Analysis of Water and Wastewater (1965).

General considerations. The observations at sampling site ' 2 ' were limited to bacteria and $\mathrm{pH}$ values. Considering that stations ' $\mathrm{o}$ ' and ' 2 ' are situated on the main stream, not very far apart, the bacterial results were combined into geometric mean estimates of the bacterial density. This is particularly valuable in case of the MPN estimates which then approach the precision of the usual 5-tube MPN. Justification for averaging the bacterial counts came from the observation that the $\mathrm{pH}$ value was almost exactly the same at the two stations, with a correlation coefficient of $+0.95^{2}$. According to this measure the physical environment at the two sampling stations was so similar at all times that very little advantage could be expected from separate treatment of their data.

\section{RESULTS}

The variation of the principal physical environmental factors during the study period is illustrated in Fig. I. The seasonal pattern of discharge was very similar at both sampling sites; the first peak being due to autumnal rains and the second due to snowmelt. The cycles of discharge and temperature were so dissimilar that their effects on other variables are mathematically separable.

The two comparable measures of acidity, $\mathrm{pH}$ value and the logarithm of titratable acidity were highly correlated at sampling site ' $O$ ' $(r=-0.954)$. At site ' $\mathrm{I}$ ' the correlation was much poorer $(r=-0.257)$ and may result from a smaller overall variation of both $\mathrm{pH}$ value and phenolphthalein acidity at that site. Nevertheless, either variable can be selected as the measure of environmental acidity, and the $\mathrm{pH}$ value was finally selected because some observations on titratable acidity were missing.

As variations in temperature have a strong influence on biological activity, and as the discharge volume affects all measurements in river studies, the results are presented in the form of four correlation matrices: the partial correlations with temperature and discharge alternately held constant, separately for the two sampling sites (Tables I, 2). In order to reduce the variability, and to equalize the variance of the bacterial counts, the logarithm has been taken for all variables except $\mathrm{pH}$ values and temperature.

Examination of Tables I to 3 brings out the following points. Sampling site ' $I$ ', the acid tributary, is rather uninteresting with respect to thiobacilli. None of the observed external factors had a statistically significant influence on either the colony count of acidophilic 


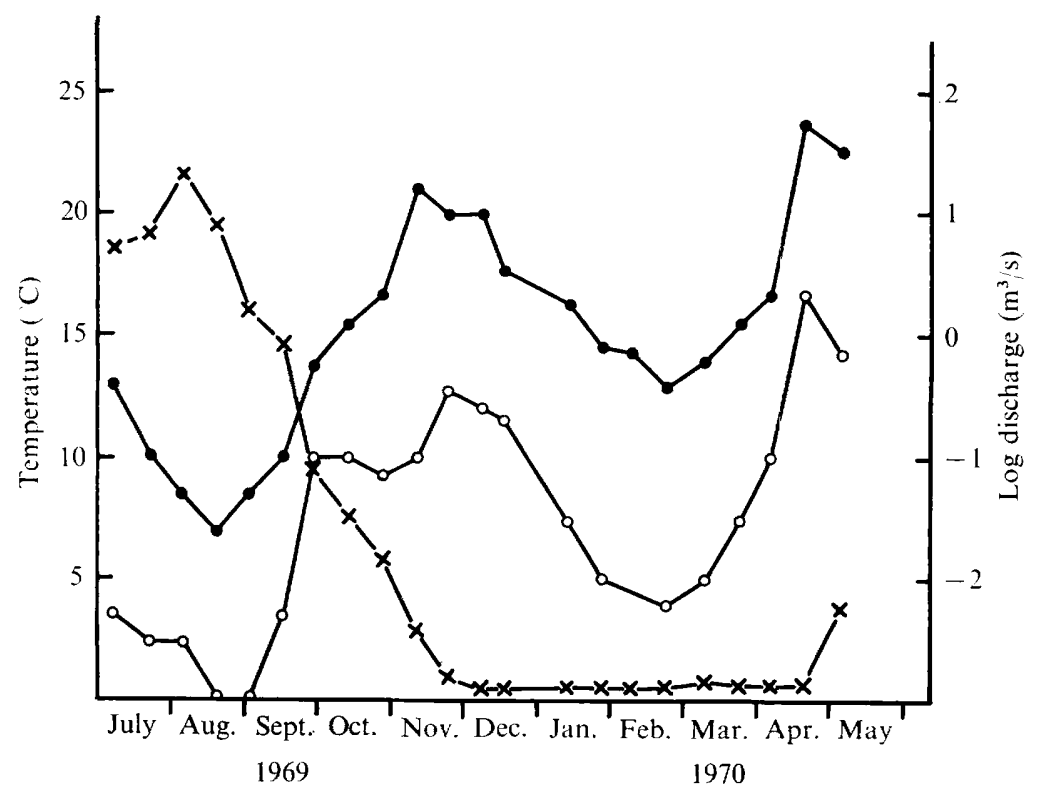

Fig. I. The physical environment in the Sirppujoki during the study period. $\times-\times$, Water temperture $\left({ }^{\circ} \mathrm{C}\right) ; 0-0$, discharge rate $\left(\mathrm{m}^{3} / \mathrm{s}\right)$ at sampling site ${ }^{\circ} \mathrm{o}^{\prime} ; 0--0$, discharge rate $\left(\mathrm{m}^{3} / \mathrm{s}\right)$ at sampling site ' $\mathrm{I}$ '.

Table I. Partial correlation coefficients, with temperature held constant

Sampling site ' $\mathrm{O}$ ' (22 observations) right of the diagonal, sampling site ' I' (I6 observations) left of the diagonal.

\begin{tabular}{|c|c|c|c|c|c|c|c|}
\hline Variable & I & 2 & 3 & 4 & 5 & 6 & 7 \\
\hline $\begin{array}{l}\text { (I) Log thiobacillus } \\
\text { count }\end{array}$ & 一 & 0.222 & 0.244 & -0.274 & 0.044 & 0.044 & -0.098 \\
\hline $\begin{array}{l}\text { (2) Log iron oxidizer } \\
\text { count }\end{array}$ & -0.496 & 一 & $0.541^{*}$ & $-0.607^{*}$ & 0.126 & 0.254 & $0.12 \mathrm{I}$ \\
\hline (3) Log discharge & 0.043 & 0.056 & - & $-0.780^{*}$ & 0.425 & 0.006 & 0.078 \\
\hline (4) $\mathrm{pH}$ & -0.130 & -0.057 & $-0.618 *$ & 一 & -0.197 & 0.429 & 0.222 \\
\hline (5) $\log \mathrm{Fe}$ conc. & 0.133 & -0.293 & -0.274 & 0.424 & - & -0.019 & -0.100 \\
\hline (6) Log Mn conc. & -0.032 & $0.26 \mathrm{I}$ & -0.314 & -0.064 & $-0.625^{*}$ & 一 & -0.181 \\
\hline (7) $\mathrm{Log} \mathrm{SO}_{4}$ conc. & -0.079 & 0.268 & -0.476 & 0.045 & -0.306 & $0.855^{*}$ & - \\
\hline
\end{tabular}

* Significant at the $95 \%$ confidence level.

thiobacilli or on the MPN count of iron oxidizers (Tables I, 2). In theory, thiobacilli numbers and acidity should be closely connected, but such a correlation was not detectable.

At station ' $O$ ' the main stream, the numbers of iron-oxidizing bacteria were significantly correlated with discharge rate and $\mathrm{pH}$ value at constant temperature (Table $\mathrm{I}$ ) and with temperature and manganese concentration at constant discharge (Table 2). A final refinement was made by calculating the partial correlations between variables, with both temperature and discharge effects simultaneously eliminated (Table 3). After this there remained no dependence of bacterial numbers on any of the chemical or physical variables, and all bacterial variation can be explained by the variations in temperature and discharge rate.

It should be stressed that plate counts of acidophilic thiobacilli did not correlate with any of the environmental variables at any stage of analysis. The plate count method may be 


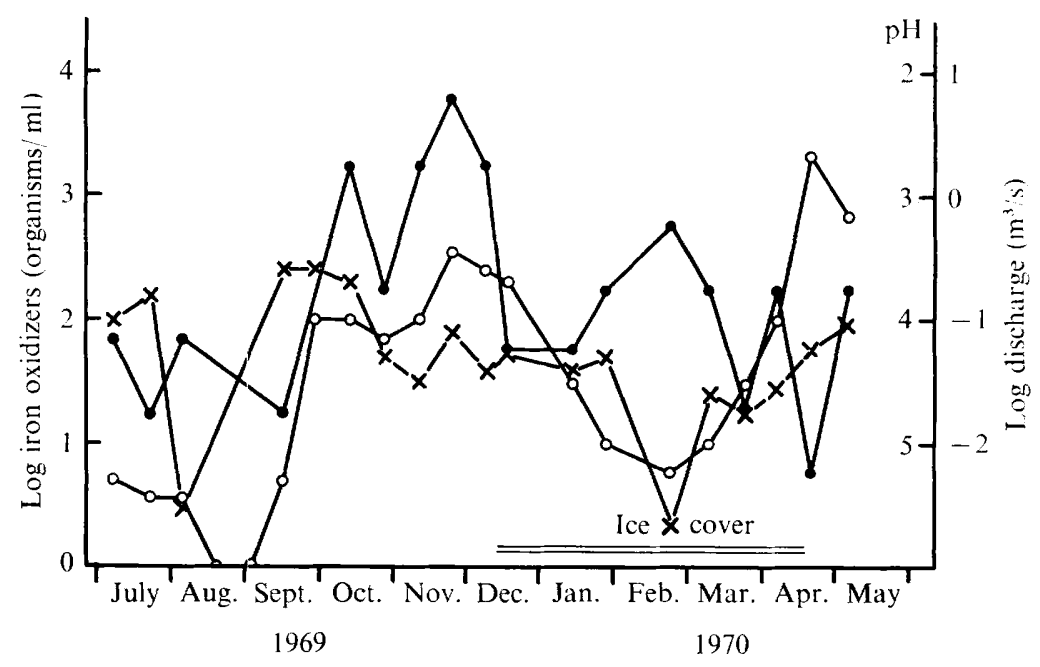

Fig. 2. Relationships of discharge rate, $\mathrm{pH}$ value (note reverse scale), and the number of iron oxidizers at sampling site ' $\mathrm{I}$ ', an acid tributary of the Sirppujoki. $\times-\times, \mathrm{pH}$ Value; $O-O$, discharge rate $\left(\mathrm{m}^{3} / \mathrm{s}\right) ;-$ number of iron oxidizers (organisms $/ \mathrm{ml}$ ).

Table 2. Partial correlation coefficients, with discharge held constant

Sampling site ' $O$ ' ( 22 observations) right of the diagonal, sampling site ' 1 ' ( 16 observations) left of the diagonal.

\begin{tabular}{|c|c|c|c|c|c|c|c|}
\hline Variable & I & 2 & 3 & 4 & 5 & 6 & 7 \\
\hline acillus & 一 & O.I 28 & -0.065 & -0.146 & -0.092 & 0.078 & -0.109 \\
\hline ron oxidizer & -0.526 & - & $-0.503^{*}$ & -0.385 & -0.365 & $-0.547^{*}$ & 0.158 \\
\hline rature & 0.222 & -0.238 & 一 & 0.170 & $0.527^{*}$ & $-0.750^{*}$ & -0.154 \\
\hline & -0.046 & 0.170 & $-0.784^{*}$ & - & 0.288 & $-0.570 *$ & -0.277 \\
\hline & 0.202 & -0.335 & -0.272 & -0.013 & - & -0.408 & -0.205 \\
\hline nc. & -0.120 & 0.363 & 0.466 & 0.176 & $-0.790^{*}$ & - & -0.003 \\
\hline $\mathrm{O}_{4}$ conc. & -0.127 & $0 \cdot 38 I$ & 0.295 & 0.018 & $-0.556^{*}$ & $0.852^{*}$ & 一 \\
\hline
\end{tabular}

* Significant at the $95 \%$ confidence level.

Table 3. Partial correlation coefficients, with both discharge and temperature held constant

Sampling site ' $O$ ' ( 22 observations) right side, sampling site ' $\mathrm{I}$ ' ( $\mathrm{I} 6$ observations) left side.

\section{Variable}

(I) Log thiobacillus count

(2) Log iron oxidizer count

(3) $\mathrm{pH}$

(4) Log Fe concentration

(5) Log Mn concentration

(6) $\mathrm{Log} \mathrm{SO}_{4}$ concentration

$$
\begin{array}{cccc}
\text { I } & 2 & 3 & 4 \\
- & 0.1 \text { II } & -0.138 & -0.068 \\
-0.499 & - & -0.352 & -0.137 \\
0.364 & -0.028 & - & 0.236 \\
0.15 \mathrm{I} & -0.289 & 0.336 & - \\
-0.019 & 0.294 & -0.345 & -0.778^{*} \\
-0.066 & 0.335 & -0.360 & -0.517
\end{array}
$$

5

6

* Significant at the $95 \%$ confidence level. 


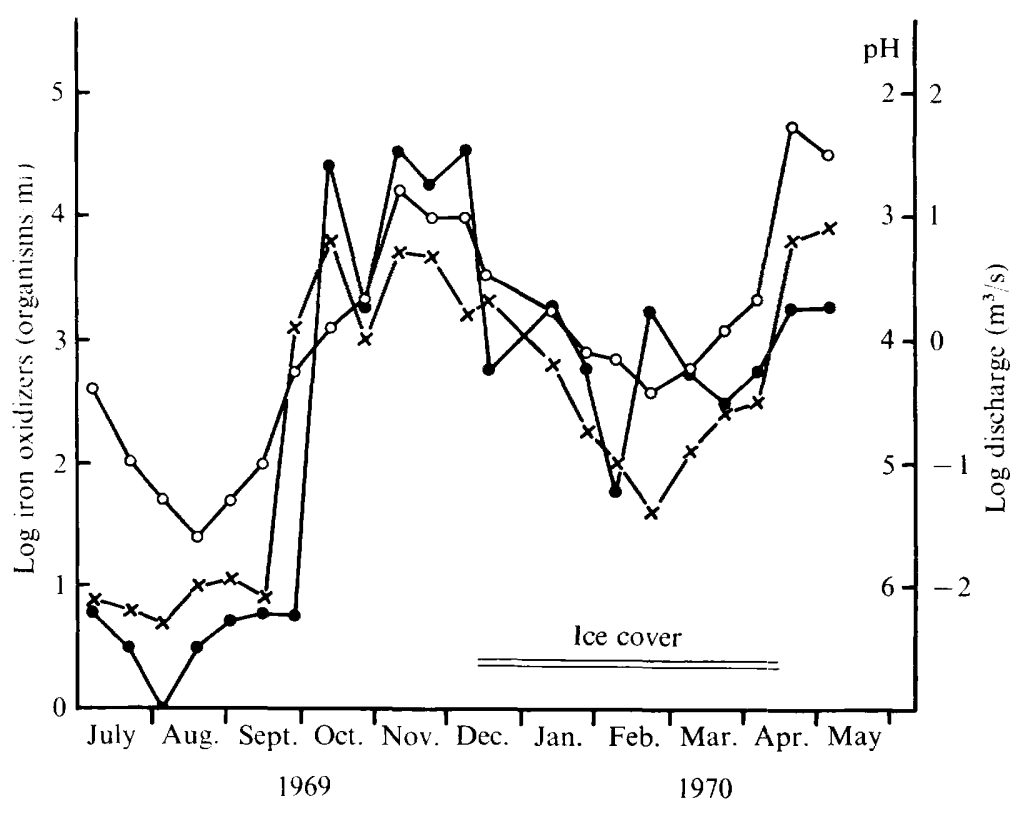

Fig. 3. Relations of discharge, $\mathrm{pH}$ (note reverse scale) and the density of iron oxidizers at sampling site ' $O$ ', the main stream of the Sirppujoki. $x-\times, \mathrm{pH}$ Value; $\mathrm{O}-\mathrm{O}$, discharge $\mathrm{rate}\left(\mathrm{m}^{3} / \mathrm{s}\right)$; number of iron oxidizers (organisms/ml).

inadequate. Not all the thiobacilli, capable of oxidizing thiosulphate at $\mathrm{pH} 4.8$ or below, can necessarily produce colonies in or on the thiosulphate-agar medium. This doubt has arisen from the observation that the growth of iron-oxidizing thiobacilli is strongly inhibited in a $\mathrm{pH}$-dependent manner by most brands of commercial agar (O. H. Tuovinen \& D. P. Kelly, unpublished data).

The somewhat surprising lack of significant correlations between bacteria and environmental variables at the acid tributary (site 'I') might be explained if the interrelations (Fig. 2) were too complicated for significant effects to emerge from such limited data as were available. It seems that the relation between discharge and bacterial numbers may be different during different times of the year, but the data are hardly sufficient for a detailed analysis.

The most important positive finding of this study is presented in Fig. 3, which illustrates the variations in number of iron oxidizers, discharge rate and $\mathrm{pH}$ value with time at sampling site ' $O$ '.

\section{DISCUSSION}

The close connexion between bacteria, discharge rate and acidity in the main stream of the Sirppujoki (Fig. 3) indicates a passive transport of both bacteria and acidity from the surrounding soil into the river by incoming waters. Such a close connexion between discharge rate and bacterial numbers seems to occur also under other circumstances when bacteria in a body of water are derived from soil by run-off waters (Kunkle \& Meiman, 1967; Korkman, I97I).

Significant positive correlations with either temperature, amounts of nutrients, or amounts of metabolic products could be interpreted as positive evidence for biological activity. None of these can be found in the present case, which indicates that thiobacilli 
probably do not find the river a suitable place for active metabolism and multiplication. This is further supported by the significant negative correlation of iron-oxidizing bacteria with temperature at sampling site ' $O$ ' (Table 2), indicating a temperature-dependent die-off effect.

The experimental work was sponsored by the Foundation for Research of Natural Resources in Finland. We thank the Uusikaupunki Water Works for providing the water samples and Mr I. Isotalo (Turku District Office of the National Board of Waters) for placing the physical and chemical data at our disposal. We are grateful to Dr D. P. Kelly for reviewing the manuscript.

\section{REFERENCES}

Burns, G. R. (1967). Oxidation of sulphur in soils. Technical Bulletin Number 13. Washington, D.C.: The Sulphur Institute.

Fisher, R. A. \& YATES, F. (196.3). Statistical Tables for Biological, Agriculturaland Medical Research, 6th edn. Edinburgh: Oliver \& Boyd.

IsotaLo, I. (197I). Mangaanin kulkeutumisesta Uudenkaupungin makean veden altaaseen. Vesitalous 12, 7-8.

Kelly, D. P. (I97I). Transformations of sulphur and its compounds in soils. Annales de l'Institut de recherche agronomique. Serie A. Annales agronomiques 22, 21 7-232.

Korkman, J. (1971). Survival and leaching of fecal streptococci under field conditions. Acta agralia fennica I23, I 86-I96.

KunkLe, S. H. \& Meiman, J. R. (1967). Water quality of mountain watersheds. Hydrology Papers, Colorado State University 21, I-53.

Purokoski, P. (1958). Die schwefelhaltigen Tonsedimente in dem Flachlandgebiet von Liminka im Lichte chemischer Forschung. Agrogeological Publications, Helsinki 7o, I-88.

Silverman, M. P. \& Lundgren, D. G. (I959). Studies on the chemoautotrophic iron bacterium Ferrobacillus ferrooxidans. I. An improved medium and a harvesting procedure for securing high cell yields. Journal of Bacteriology 77, 642-647.

Standard Methods for the Analysis of Water and Wastewater (1965), 12th edn New York: American Public Health Association.

Tuovinen, O. H., Niemelä, S. I. \& GyllenberG, H. G. (1971). Effect of mineral nutrients and organic substances on the development of Thiobacillus ferrooxidans. Biotechnology and Bioengineering 13, 517-527. 